\title{
Citrus Sinensis cultivars: alternatives for diversification of brazilian orchards
}

\author{
Charlismilã Amorim do Couto ${ }^{1}$, Eli Regina Barboza de Souza ${ }^{2}$, \\ Cristiane Maria Ascari Morgado ${ }^{3}$, Toshio Ogata ${ }^{4}$, Luís Carlos Cunha Júnior ${ }^{5}$
}

\begin{abstract}
This work aimed to evaluate the physicochemical characteristics of different orange cultivars (Citrus sinensis) in order to identify those with potential to the consumer market and/or for processing. Five orange cultivars were evaluated: 'Natal IAC', 'Natal 112', 'Pera IAC 2000', 'Pera IAC', 'Baianinha' and 'Pera Rio', which were harvested at maturation stage considered ideal for commercialization in the "Agência Goiana de Assistência Técnica, Extensão Rural e Pesquisa Agropecuária - EMATER" experimental orchard at the municipality of Anápolis, state of Goiás. After harvesting, fruits were transported to the laboratory, selected, standardized, washed and allowed to dry. Subsequently, skin color, longitudinal and cross-sectional diameter, number of seeds, fruit and juice, yield, levels of soluble solids, ascorbic acid and total extractable polyphenols, $\mathrm{pH}$ and total antioxidant capacity analyses were conducted. Among cultivars studied, 'Baianinha' and 'Pera IAC' can be alternatives to citrus growers, with potential to be accepted among consumers and processing industries.

Index-terms: orange, fruit quality, titratable acidity, soluble solids, ascorbic acid, total extractable polyphenols.
\end{abstract}

\section{Cultivares de Citrus sinensis: alternativas para diversificação dos pomares brasileiros}

Corresponding author:

charliscouto@hotmail.com

Received: October 26, 2017. Accepted: April 11, 2018

Copyright: All the contents of this journal, except where otherwise noted, is licensed under a Creative Commons Attribution License.

\section{(cc) $\mathrm{EY}$}

Resumo - Este trabalho teve como objetivo avaliar as características físico-químicas de diferentes cultivares de laranja (Citrus sinensis), visando à identificação daquelas com potencial para o mercado consumidor e/ou para processamento. Foram avaliadas cinco cultivares de laranja: Natal IAC, Natal 112, Pera IAC 2000, Pera IAC, Baianinha e Pera Rio, as quais foram colhidas no estádio de maturação, considerado ideal para comercialização, em pomar experimental da Agência Goiana de Assistência Técnica, Extensão Rural e Pesquisa Agropecuária (EMATER), localizada em Anápolis, Goiás (GO). Após a colheita, os frutos foram transportados ao laboratório, onde foram selecionados, padronizados, lavados e deixados secar. Posteriormente, realizaram-se análises de coloração da casca, diâmetro longitudinal e transversal, número de sementes, massa do fruto e do suco, rendimento, teores de acidez titulável, de sólidos solúveis, de ácido ascórbico e de polifenóis extraíveis totais, $\mathrm{pH}$ e capacidade antioxidante total. Entre as cultivares estudadas, a 'Baianinha' e a 'Pera IAC' podem ser alternativas de copa aos produtores de citros, com potencial de serem aceitas entre os consumidores e indústrias processadoras.

Termos para indexação: laranja, qualidade de fruto, acidez titulável, sólidos solúveis, ácido ascórbico, polifenóis extraíveis totais.

\footnotetext{
${ }^{1}$ Agronomist, MSc in Plant Production at Federal University of Goiás, School of Agronomy, Campus of Samambaia, Goiânia - GO, Brazil. Email: charliscouto@hotmail.com

${ }^{2} \mathrm{PhD}$ in Agronomy (Plant Production), Adjunct Professor at Federal University of Goiás, School of Agronomy, Campus of Samambaia, Goiânia - GO. Brazil. Email: eliregina1@gmail.com

${ }^{3} \mathrm{PhD}$ in Agronomy (Plant Production), Post-Doctorate at Federal University of Goiás, School of Agronomy, Campus of Samambaia, Goiânia - GO. Brazil. Email: cristianemorgado4@yahoo.com.br

${ }^{4}$ Master's degree in Agronomy (Plant Technology), Rural Development Analyst at the Agency for Technical Assistance and Agricultural Research of Goiás, Experimental Station of Anápolis. Anápolis-GO. Brazil. Email: t.ogata@hotmail.com

${ }^{5} \mathrm{PhD}$ in Agronomy (Plant Science), Adjunct Professor at Federal University of Goiás, School of Agronomy, Campus of Samambaia, Goiânia - GO. Brazil. Email: cunhajunior.1.c@gmail.com
} 


\section{Introduction}

Sweet orange (Citrus sinensis) is a fruit belonging to the Ruthaceae family, has high ascorbic acid levels (vitamin C) and significant content of antioxidants such as betacarotene and flavonoid compounds (SNART et al., 2007). Brazil is the world's largest orange producer (OECD / FAO, 2015, SNART et al., 2007) and the world's largest exporter of processed citrus fruits, especially concentrated orange juice (OECD / FAO, 2015).

The state of Goiás is considered an emerging producer in the citrus market, both for the quality of its fruits as for its favorable geographical position, which guarantees easy production flow and acceptance of its fruits in consumer markets (CASTRO et al., 2014). Regarding the midwestern region of Brazil, the state of Goiás is the main orange producer, with production of 156,225 tons, in 2016 (IBGE, 2016).

Although citriculture is one of the most important economic activities in Brazil, it is supported by a small number of cultivars (MACHADO et al., 2011), mainly focused on industrialization. Among cultivars, 'Pera Rio' cultivar stands out as the most important Brazilian citrus variety, being used by the industry and for the internal fresh fruit market. Fruits of this cultivar have good acceptability by the consumer, presenting good appearance, sweeter taste and low acidity, being excellent for fresh consumption and processing, thus obtaining the preference of producers and consumers. However, it is necessary to study new cultivars to meet recent consumer market and phytosanitary requirements (SALIBE et al., 2002). The requirements to be met by the citrus fruit production segment are related to phytosanitary characteristics, color, size, flavor, juice, acidity, among other factors (BORGES; TOLEDO, 1999).

Due to these requirements, citrus growers who destine their production to the fresh fruit market are changing the profile of their orchards, presenting greater diversification of cultivars. For the genetic diversity study, it is important to analyze the morphoagronomic and physicochemical characteristics, considering that the potential of using different cultivars for several breeding programs based on the genetic diversity evaluation of citrus cultivars (NEGREIROS et al., 2014).

New selected cultivars must present good characteristics and meet the quality demands of market, making the evaluation of fruit quality essential (MACHADO et al., 2011) and SCHWARZ (2011). This is due to the fact that the classic citrus improvement aims mainly to obtain cultivars presenting high productivity, fruits with few seeds, high juice content, attractive coloring, as well as a balance between sugar content and acidity.
The aim of this work was to evaluate the physicochemical characteristics of different orange cultivars available in market, aiming at the identification of those with potential for the consumer market and / or processing industry in the central region of the state of Goiás.

\section{Material and methods}

The experiment was conducted in an experimental orchard of the "Agência Goiana de Assistência Técnica, Extensão Rural e Pesquisa Agropecuária - EMATER", located in the municipality of Anápolis, central region of Goiás, under coordinates $16^{\circ} 19^{\prime} \mathrm{S}$ and $48^{\circ} 18^{\prime} \mathrm{W}$, with average altitude of $980 \mathrm{~m}$ a.s.1. The climate of the region is Aw type, hot and humid with six months of dry winter, according to the Köppen and Geiger classification (1928). The soil is classified as Eutrophic Red Latosol. The orchard was planted on October 29, 2009, at 7 × $6 \mathrm{~m}$ spacing, under conventional management system and use of additional irrigation in the dry periods. Irrigation was performed by micro sprinkler ( 40 to $50 \mathrm{~mm}$ of water per plant per day). Annually, cleaning pruning is performed after harvesting. In addition, cultivars are grafted on 'Rangpur' lime and fertilization adopted recommendations of the IAC 100 Bulletin for citriculture.

Mature fruits were manually harvested on July and August 2016 at the maturation stage considered ideal for commercialization, defined by the ratio between soluble solids and titratable acidity (SS / TA) equal to 9.5 (BRASIL, 2000).

Sweet orange cultivars $(C$. sinensis $)$ used in the experiment were 'Natal IAC', 'Natal 112', 'Pera IAC 2000', 'Pera IAC' and 'Baianinha', as well as 'Pera Rio' commercial cultivar, which was used as parameter of acceptance by consumers.

Fruits were harvested from 10 plants, totalizing a box of $20 \mathrm{~kg}$ for each cultivar. After harvesting, boxes were transported to the Laboratory of Horticulture of the Federal University of Goiás. In the laboratory, fruits of each cultivar were washed, allowed to dry and each sample was composed of 30 randomly selected fruits. The following physical variables were evaluated: fruit and juice mass, juice yield, cross-sectional and longitudinal diameter, number of seeds and skin color. Fruit and juice mass was obtained with the aid of a precision scale and results were expressed in grams (g). Fruit yield (\%) was obtained by calculating the juice weight / fruit weight ratio. Fruit diameter was measured at the central region using a digital caliper. Results were expressed in millimeters $(\mathrm{mm})$ and the number of seeds was obtained by direct counting. For these analyses, 30 replicates were used, where each fruit composed a replicate. 
Skin color was determined using Hunter Color Quest II Sphere colorimeter, obtaining the following chromatic attributes: $L^{*}, a^{*}$ and $b^{*}$ and from these, it was possible to calculate the $\mathrm{C}^{*}$ (chroma) and $\mathrm{h}$ * (Hue or color angle) values according to McGuire (1992). Color was determined on 15 fruits of each cultivar, with two readings on opposite sides in the equatorial region.

For chemical analyses, soluble solids (SS) and titratable acidity (TA), $\mathrm{pH}$, ascorbic acid content, total extractable polyphenols and total antioxidant activity were determined by the Ferric Reducing Antioxidant Power (FRAP) method. For the determination of analyses, 10 replicates with 3 fruits each were used for each cultivar. SS contents were determined by refractometry using portable refractometer, with results expressed in percentage (\%). TA contents were determined by titration with $0.1 \mathrm{~N}$ $\mathrm{NaOH}$, using phenolphthalein as indicator and results were expressed as \% citric acid (INSTITUTO ADOLFO LUTZ, 2008).

The $\mathrm{pH}$ values were determined with the help of $\mathrm{pH}$ meter by the potentiometric method (INSTITUTO ADOLFO LUTZ, 2008). The ascorbic acid contents were determined by the Tillmans method, and results were expressed as $\mathrm{mg}$ ascorbic acid $100 \mathrm{~g}^{-1}$ juice (STROCKER; HENNING, 1967). The contents of total extractable polyphenols were determined using the Folin-Ciocalteu method (RUFINO, 2008), with results expressed in mg gallic acid $100 \mathrm{~g}^{-1}$ pulp. The total antioxidant capacity was determined by the FRAP method and results were expressed in $\mu \mathrm{mol}$ ferrous sulphate $\mathrm{g}^{-1}$ pulp (RUFINO, 2008).

Data were submitted to the univariate analysis of variance and means were compared by the Scott-Knott test at $5 \%$ probability using the Sisvar software (FERREIRA, 2014). Data were also submitted to the cluster analysis by Ward's method, considering the Euclidean distance as a measure of dissimilarity among cultivars (HAIR et al., 2005) using Statistica software (STATSOFT INC., 2004).

\section{Results and discussion}

According to Reis et al. (2016), the external evaluation of fruits involves combinations of geometric and physical attributes, which directly influence the acceptability by consumers. The external dimensions of fruits presented significant differences among cultivars, and the 'Baianinha' cultivar presented the largest longitudinal diameter, followed by 'Pera IAC', 'Pera IAC 2000', 'Natal IAC' cultivars, which are equal to each other, and higher than 'Natal 112' cultivar, which in turn, was higher than 'Pera Rio' cultivar (Table 1). On the other hand, 'Pera IAC 2000' cultivar showed the highest cross-sectional diameter, followed by 'Natal IAC' cultivar, higher than 'Natal 112', 'Baianinha' and 'Pera Rio' cultivars, which were statistically similar and higher than 'Pera IAC' cultivar.

Oliveira and Scivittaro (2011) observed that cultivars that show absence or few seeds have gained space in the Brazilian market, and this requirement is greater when the production of high-quality fruits is destined to the international market, where there is tolerance in relation to the number of seeds by citrus fruit, being considered as seedless those that present average of up to two seeds per fruit. All cultivars presented seeds, and the 'Natal IAC' cultivar presented the lowest amount of seeds, while 'Pera Rio' and 'Pera IAC 2000' commercial cultivars were statistically equal and higher than the others (Table 1). The number of seeds was much lower than that found by Pacheco et al. (2014), who evaluated fruit and juice of TMxLP 290 hybrid in the July 2012 harvest and found 22 seeds per fruit.

Statistical differences were observed among evaluated cultivars, regarding fruit mass, juice and yield. Fruit mass followed the same trend of longitudinal and cross-sectional diameters, that is, larger fruits presented the largest masses. 'Baianinha', 'Pera IAC 2000' and 'Natal IAC' cultivars obtained the highest averages (204.54 g, $204.27 \mathrm{~g}$ and $198.72 \mathrm{~g}$, respectively), statistically similar to each other and higher than the others, followed by 'Natal 112' and 'Pera IAC' cultivars, higher than 'Pera Rio' cultivar. Arruda et al. (2011) in work with 'Pera' orange from organic and conventional cultivars, found higher average fruit mass, with $185.12 \mathrm{~g}$ for conventional cultivation with post-harvest treatment with imazalil $\left(1000 \mathrm{~g} \mathrm{~mL}^{-1}\right)$ and $183.70 \mathrm{~g}$ without imazalil and 176.23 $\mathrm{g}$ in organic cultivation, results close to those found in the present study for 'Pera Rio' and 'Pera IAC' cultivars.

'Baianinha' cultivar presented the highest amount of juice, followed by 'Pera IAC', 'Pera IAC 2000' and 'Natal 112' cultivars, similar to each other and higher than 'Natal IAC' and 'Pera Rio' cultivars. Regarding yield, 'Pera IAC', 'Baianinha' and 'Natal 112' cultivars presented the best statistically similar results, higher than 'Pera Rio', 'Pera IAC 2000' and 'Natal IAC' cultivars, which presented similar results (Table 1). According to CEAGESP (2011), each group of cultivars presents different yield requirements, for 'Bahia' $35 \%$, 'Natal' $44 \%$ and 'Pera' $45 \%$. Following these requirements, in the present study, 'Baianinha' (48.70\%), 'Natal 112' (45.97\%), and 'Pera IAC' cultivars (49.43\%) presented higher results, while 'Pera Rio' (43.67\%), 'Pera IAC' (42.15\%) and 'Natal IAC' cultivars (40.42\%) presented values close to established values.

According to Teixeira (2009) and Batista (1994), the chromatic attributes are also related to the purchase intention of consumers, being a parameter of fundamental importance in the judgment of product quality. Generally, the consumer's first contact with a product is with the visual presentation, and color is the main criterion used in the acceptance or rejection of the product. In addition, 
the genetic variation influences the different color shades of fruits, conferring different variations on the skin color (CASTRICINI et al., 2015). 'Pera IAC' cultivar showed lighter skin (higher L value) compared to the other cultivars, followed by 'Pera IAC 2000', 'Natal 112' and 'Pera Rio' cultivars, similar to each other and higher than 'Natal IAC' and 'Baianinha' cultivars (Table 2). Regarding chromaticity - color intensity - (C), there was a significant difference among cultivars, with the highest value observed for 'Pera IAC' cultivar, followed by 'Pera Rio' cultivar, which was statistically higher than 'Baianinha' cultivar and to 'Pera IAC 2000', 'Natal 112' and 'Natal IAC' cultivars. According to Medina et al. (2005), such changes in fruit skin color occurs due to the degradation of chlorophyll and the synthesis of carotenoids, pigments responsible for the yellow or orange coloration of fruits.

For the hue angle indicating fruit color, 'Baianinha' and 'Pera IAC' cultivars presented the highest values, followed by 'Pera Rio', 'Pera IAC 2000', 'Natal IAC' and 'Natal 112' cultivars, which are similar to one another. It should be noted that all cultivars presented values higher than 70, indicating yellow-orange skin color, which is an attractive feature for the consumer.

The hierarchical grouping analysis considering the physical and chromatic characteristics was used to verify the behavior of cultivars in relation to 'Pera Rio' cultivar, which was used as a comparison parameter. The dendrogram generated from cluster analysis (hierarchical) clearly showed the formation of 3 distinct groups, when the cutoff point of $30 \%$ dissimilarity was used. Thus, it was possible to highlight three groups of interest, group 1 formed by 'Baianinha' cultivar, group 2 formed by 'Natal 112', 'Natal IAC' and 'Pera IAC 2000' cultivars and group 3 formed by 'Pera IAC' and 'Pera Rio' cultivars ( Figure 1).

The physical characteristics of 'Baianinha' cultivar make this cultivar a good choice for both processing industry (high juice yield) and for the fresh consumption market for the size of fruits and number of seeds. On the other hand, 'Pera IAC' cultivar was another alternative to 'Pera Rio' cultivar because it presents similar physical characteristics, which is attractive to consumers.

In a cluster analysis performed by Santos et al. (2016) for morphoagronomic and physicochemical characterization of citrus germplasm, five groups were formed with cutoff point of $25 \%$ dissimilarity, where 'Bahia', 'Pera Rio' and 'Natal' cultivars were in the same group, results different from the present study, where for the physical characteristics, 'Baianinha' cultivar had no similarity with any group. These differences can be explained by the difference in the grouping techniques used in each study, as well as by the characteristics evaluated, or by the effect of the cultivar environment or by the characteristics of a specific harvest season (CERQUEIRA et al., 2004; SOUZA et al., 2005; DUARTE et al., 2011; PACHECO et al., 2014).

The titratable acidity contents presented significant differences among cultivars. 'Baianinha' cultivar presented the highest levels, followed by 'Natal 112' and 'Natal IAC' cultivars, similar to each other and higher than 'Pera IAC 2000' and 'Pera IAC' cultivars, which in turn were higher than 'Pera Rio' cultivar (Table 3). These results corroborate those observed by Couto and CanniattiBrazaca (2010), who in a characterization study of citrus cultivars, presented 'Bahia' cultivar with the highest value ( $1.48 \%$ citric acid) followed by 'Natal' cultivar e (1.24\% citric acid). Teruel et al. (2000) observed citric acid values of $0.75 \%$ for 'Baianinha' cultivar, in addition to a decrease in contents during the storage period at room temperature $\left(21 \pm 0.4^{\circ} \mathrm{C}\right.$ and $\left.60 \pm 1.0 \% \mathrm{RH}\right)$ or refrigeration $(1 \pm 0.5$ ${ }^{\circ} \mathrm{C}$ and $\left.85 \pm 2.5 \% \mathrm{RH}\right)$, values lower than those found in this study.

Pacheco et al. (2014) reported titratable acidity levels of $1.1 \mathrm{~g} 100 \mathrm{~mL}^{-1}$ of juice for TMxLP 290 hybrid, which was similar to contents found in this study for 'Natal IAC' and 'Natal 112' cultivars. Pereira et al. (2006) reported that the acidity values in ripe orange and mandarin fruits should be between 0.5 and $1.0 \%$ citric acid. Following this criterion, only 'Pera IAC' and 'Pera IAC 2000' cultivars are within established standards.

According to the norms of citrus classification (CEAGESP, 2011), fruits with values lower than 10\% are classified as low-quality fruits; however, it should be noted that differences smaller than $1^{\circ}$ Brix are not perceptible to the palate of orange consumers; however, lower differences are noticeable in the pulp concentrate industry. According to Pereira et al. (2006) ideal values of soluble solids for harvesting should be around 9.0 to $10.0 \%$. Thus, for soluble solids, 'Pera Rio' cultivar presented the highest concentration, followed by 'Natal 112 ' cultivar, and higher than 'Baianinha' and 'Pera IAC 2000' cultivars, which were statistically similar and higher than 'Natal IAC' and 'Pera IAC' cultivars (Table 3), with $X$ and $X$ below levels considered ideal. Tazina et al. (2010) in a study of production and quality of 'Pera' orange clones found values above $10.65 \%$ for the three tested clones.

The ratio serves as indicative of the maturation stage, by determining the sweet: acid taste balance (COUTO; CANNIATTI-BRAZACA, 2010). The ratio values can range from 6 to 20, with consumers around the world preferring citrus juices with ratio from 14 to 16. In the juice industry, the ratio should be between 12 and 18 for processing (POZZAN; TRIBONI, 2005). The ratio values in the cultivars studied ranged from 7.82 ('Baianinha') to 24.94 ('Pera Rio').

Therefore, 'Pera IAC 2000' and 'Pera IAC' cultivars are indicated for use in the juice industry, while the others did not meet these parameters. 'Pera Rio' cultivar, considered to be preferred by consumers, presented high SS / TA ratio due to its low titratable acidity levels. 
Ascorbic acid showed significant differences among cultivars, especially for 'Baianinha' cultivar, followed by 'Natal 112' cultivar, which was higher than 'Pera IAC', 'Pera Rio', 'Pera IAC 2000' and 'Natal IAC' cultivars, which were statistically similar (Table 3). 'Baianinha' cultivar was the only one that presented value lower than that described for it in the Brazilian Table of Food Composition (UNICAMP, 2011), which is of $94.5 \mathrm{mg}$ of ascorbic acid $100 \mathrm{~mL}^{-1}$ of juice, while 'Pera Rio', 'Pera IAC', 'Pera IAC 2000' and 'Natal IAC' cultivars presented the lowest ascorbic acid values (Table 3 ), compared to results described in the UNICAMP table (2011), which was $73.3 \mathrm{mg}$ for 'Pera Rio' cultivar. Couto and Canniatti-Brazaca (2010) evaluated the ascorbic acid content of orange cultivars and obtained higher ascorbic acid levels for 'Bahia', 'Natal' and 'Pera' cultivars.

'Pera IAC' cultivar presented the highest total levels of extractable polyphenols, followed by 'Pera IAC', 'Natal IAC', 'Natal 112' and 'Baianinha' cultivars, similar to each other and higher than 'Pera Rio' cultivar (Table 4). The total antioxidant capacity, determined by the iron reduction method (FRAP), was higher in 'Pera IAC' and 'Baianinha' cultivars, followed by 'Pera IAC 2000', 'Natal IAC' and 'Natal 112' cultivars, and higher than 'Pera Rio' cultivar (Table 4).

In the case of 'Pera IAC' cultivar, the antioxidant capacity determined by the iron reduction method (FRAP) was not directly related to the ascorbic acid content. This result may have occurred due to the higher accumulation of other phenolic compounds important for antioxidant capacity, in addition to vitamin C (HALLIWELL, 2001; YU et al., 2002). However, a trend between total levels of extractable polyphenols and antioxidant activity was observed, in which fruits with higher levels of total polyphenols may present higher antioxidant activity, as in the case of this cultivar (Table 4).
On the other hand, 'Baianinha' cultivar showed higher ascorbic acid values (Table 3 ), high total antioxidant activity and intermediate total levels of extractable polyphenols (Table 4). Therefore, this cultivar has satisfactory values of bioactive compounds and its antioxidant activity may have been influenced by the ascorbic acid contents.

When considering the chemical attributes and total antioxidant activity, the clustering analysis indicated that the cultivars formed three groups, considering the cutoff point of $15 \%$ dissimilarity, where group 1 is formed by 'Baianinha' and 'Natal 112' cultivars, group 2 by 'Natal IAC', 'Pera IAC 2000' and 'Pera IAC' and group 3 only by 'Pera Rio' cultivar (Figure 2).

According to Figure 2, none of the cultivars presented similarity to 'Pera Rio' cultivar, which may have occurred because it presented the highest soluble solids and $\mathrm{pH}$ values and the lowest titratable acidity, ascorbic acid and polyphenols, in addition to low total antioxidant activity, as observed in the univariate analysis. In addition, some cultivars considered similar in relation to physical and chromatic characteristics (Figure 1) differed in relation to chemical characteristics (Figure 2), demonstrating the importance of evaluating physical and chemical attributes for genotype characterization.

Table 1. Longitudinal diameter ( $\mathrm{mm})$, cross-sectional diameter $(\mathrm{mm})$, number of seeds, fruit mass $(\mathrm{g})$, juice weight (g) and yield (\%) of orange cultivars from the experimental orchard of the Agency for Technical Assistance and Agricultural Research of Goiás (EMATER), Anápolis, Goiás, 2016.

\begin{tabular}{lcccccc}
\hline \multirow{2}{*}{ Cultivars } & DL $^{*}$ & $\mathrm{DT}^{*}$ & NS $^{*}$ & MF $^{*}$ & Juice $^{*}$ & Yield $^{*}$ \\
\cline { 2 - 6 } & $(\mathrm{mm})$ & $(\mathrm{mm})$ & $\left(\mathrm{n}^{\mathrm{o}}\right)$ & $(\mathrm{g})$ & $(\mathrm{g})$ & $(\%)$ \\
\hline Pera Rio & $66.52 \mathrm{~d}$ & $70.57 \mathrm{c}$ & $7.10 \mathrm{a}$ & $170.83 \mathrm{c}$ & $74.49 \mathrm{c}$ & $43.67 \mathrm{~b}$ \\
Pera IAC & $71.96 \mathrm{~b}$ & $67.82 \mathrm{~d}$ & $5.33 \mathrm{~b}$ & $179.51 \mathrm{~b}$ & $88.43 \mathrm{~b}$ & $49.43 \mathrm{a}$ \\
Pera IAC 2000 & $71.24 \mathrm{~b}$ & $77.42 \mathrm{a}$ & $6.37 \mathrm{a}$ & $204.27 \mathrm{a}$ & $84.91 \mathrm{~b}$ & $42.15 \mathrm{~b}$ \\
Natal IAC & $72.00 \mathrm{~b}$ & $74.07 \mathrm{~b}$ & $4.37 \mathrm{c}$ & $198.72 \mathrm{a}$ & $78.82 \mathrm{c}$ & $40.42 \mathrm{~b}$ \\
Natal 112 & $69.38 \mathrm{c}$ & $72.24 \mathrm{c}$ & $5.10 \mathrm{~b}$ & $185.59 \mathrm{~b}$ & $84.61 \mathrm{~b}$ & $45.97 \mathrm{a}$ \\
Baianinha & $75.42 \mathrm{a}$ & $71.27 \mathrm{c}$ & $5.63 \mathrm{~b}$ & $204.54 \mathrm{a}$ & $99.48 \mathrm{a}$ & $48.70 \mathrm{a}$ \\
\hline
\end{tabular}

*Averages followed by the same letter in the column do not differ by the Scott-Knott's test at 5\%. Significant at 1\% for the F test. DL: Longitudinal diameter; DT: Cross-sectional diameter; NS: Number of seeds; MF: Fruit mass. 
Table 2. Luminosity, chromaticity and hue angle of orange skin from the experimental orchard of the Agency for Technical Assistance and Agricultural Research of Goiás (EMATER), Anápolis, Goiás, Brazil, 2016.

\begin{tabular}{lccc}
\hline Cultivars & $\mathrm{L}^{*}$ & $\mathrm{C}^{*}$ & Hue angle $^{*}$ \\
\hline Pera Rio & $57.59 \mathrm{~b}$ & $81.63 \mathrm{~b}$ & $79.65 \mathrm{~b}$ \\
Pera IAC & $62.74 \mathrm{a}$ & $93.94 \mathrm{a}$ & $82.93 \mathrm{a}$ \\
Pera IAC 2000 & $59.60 \mathrm{~b}$ & $50.26 \mathrm{~d}$ & $78.30 \mathrm{~b}$ \\
Natal IAC & $53.90 \mathrm{c}$ & $43.94 \mathrm{~d}$ & $77.52 \mathrm{~b}$ \\
Natal 112 & $58.20 \mathrm{~b}$ & $47.70 \mathrm{~d}$ & $75.94 \mathrm{~b}$ \\
Baianinha & $52.31 \mathrm{c}$ & $74.62 \mathrm{c}$ & $82.15 \mathrm{a}$ \\
\hline
\end{tabular}

*Averages followed by the same letter in the column do not differ by the Scott-Knott's test at 5\%.Significant at 1\% for the F test. L: Luminosity; C: Chromaticity.

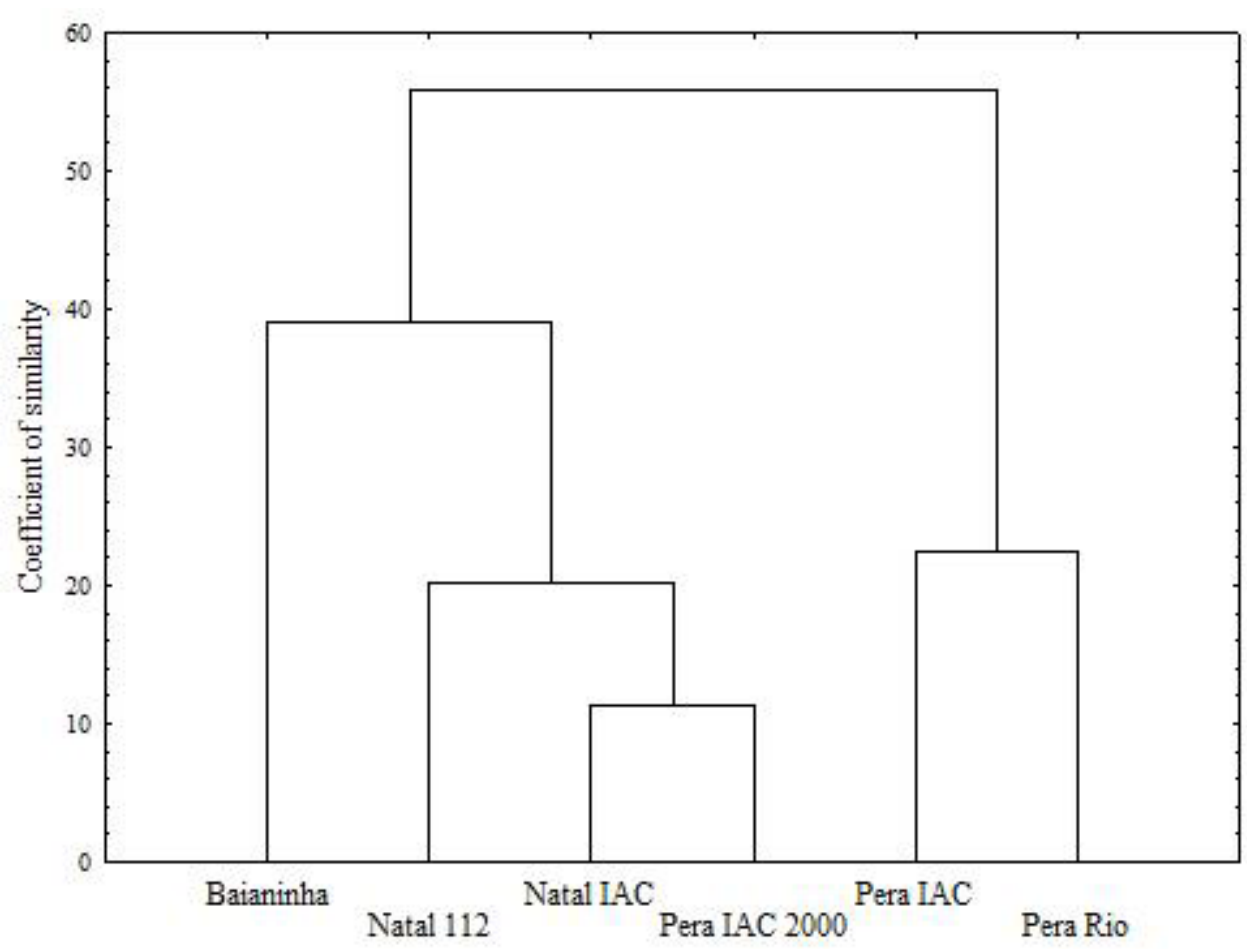

Figure 1. Dendrogram showing the general Euclidean distance among orange cultivars in relation to their physical and chromatic characteristics, from the experimental orchard of the Agency for Technical Assistance and Agricultural Research of Goiás (EMATER), Anápolis, Goiás, Brazil.

Table 3. Titratable acidity (TA in \% citric acid), soluble solids (SS in \%), SS / TA ratio, ascorbic acid content (mg ascorbic acid $100 \mathrm{~mL}^{-1}$ juice) and $\mathrm{pH}$ of cultivars from the experimental orchard of the Agency for Technical Assistance and Agricultural Research of Goiás (EMATER), Anápolis, Goiás, 2016.

\begin{tabular}{lccccc}
\hline \multirow{2}{*}{ Cultivars } & TA $^{*}$ & \multicolumn{1}{c}{$\mathrm{SS}^{*}$} & SS/TA & Ascorbic acid & \multirow{2}{*}{$\mathrm{pH}^{*}$} \\
\cline { 2 - 5 } & $(\%$ citric acid $)$ & $(\%)$ & & $\left(\mathrm{mg} 100 \mathrm{~mL}^{-1}\right)$ & \\
\hline Pera Rio & $0.45 \mathrm{~d}$ & $10.95 \mathrm{a}$ & $24.94 \mathrm{a}$ & $40.00 \mathrm{c}$ & $4.44 \mathrm{a}$ \\
Pera IAC & $0.74 \mathrm{c}$ & $8.53 \mathrm{~d}$ & $11.96 \mathrm{~b}$ & $41.01 \mathrm{c}$ & $3.37 \mathrm{c}$ \\
Pera IAC 2000 & $0.81 \mathrm{c}$ & $9.27 \mathrm{c}$ & $11.94 \mathrm{~b}$ & $39.48 \mathrm{c}$ & $3.48 \mathrm{~b}$ \\
Natal IAC & $1.05 \mathrm{~b}$ & $8.80 \mathrm{~d}$ & $9.12 \mathrm{c}$ & $38.44 \mathrm{c}$ & $3.54 \mathrm{~b}$ \\
Natal 112 & $1.08 \mathrm{~b}$ & $9.76 \mathrm{~b}$ & $9.05 \mathrm{c}$ & $48.70 \mathrm{~b}$ & $3.34 \mathrm{c}$ \\
Baianinha & $1.21 \mathrm{a}$ & $9.43 \mathrm{c}$ & $7.82 \mathrm{c}$ & $54.36 \mathrm{a}$ & $3.07 \mathrm{~d}$ \\
\hline
\end{tabular}

*Averages followed by the same letter in the column do not differ by the Scott-Knott's test at $5 \%$. Significant at $1 \%$ by the F test. 
Table 4. Total levels of extractable polyphenols (mg gallic acid $100 \mathrm{~g}^{-1}$ pulp) and total antioxidant activity ( $\mu$ mol ferrous sulphate $\mathrm{g}^{-1}$ pulp) of orange cultivars from the experimental orchard of the Agency for Technical Assistance and Agricultural Research of Goiás (EMATER), Anápolis, Goiás, 2016

\begin{tabular}{lcc}
\hline \multirow{2}{*}{ Cultivars } & Total extractable polyphenols $^{*}$ & Total antioxidant activity $^{*}$ \\
\cline { 2 - 3 }$\left({\left.\text { mg gallic acid } 100 \mathrm{~g} \mathrm{~g}^{-1} \text { pulp }\right)}\right.$ & $\left(\mu\right.$ mol ferrous sulphate $\mathrm{g}^{-1}$ pulp $)$ \\
\hline Pera Rio & $11.52 \mathrm{c}$ & $6.15 \mathrm{c}$ \\
Pera IAC & $31.88 \mathrm{a}$ & $9.79 \mathrm{a}$ \\
Pera IAC 2000 & $24.62 \mathrm{~b}$ & $8.13 \mathrm{~b}$ \\
Natal IAC & $23.18 \mathrm{~b}$ & $7.37 \mathrm{~b}$ \\
Natal 112 & $23.97 \mathrm{~b}$ & $7.40 \mathrm{~b}$ \\
Baianinha & $24.50 \mathrm{~b}$ & $9.13 \mathrm{a}$ \\
\hline
\end{tabular}

*Averages followed by the same letter in the column do not differ by the Scott-Knott's test at 5\%. Significant at $1 \%$ by the F test.

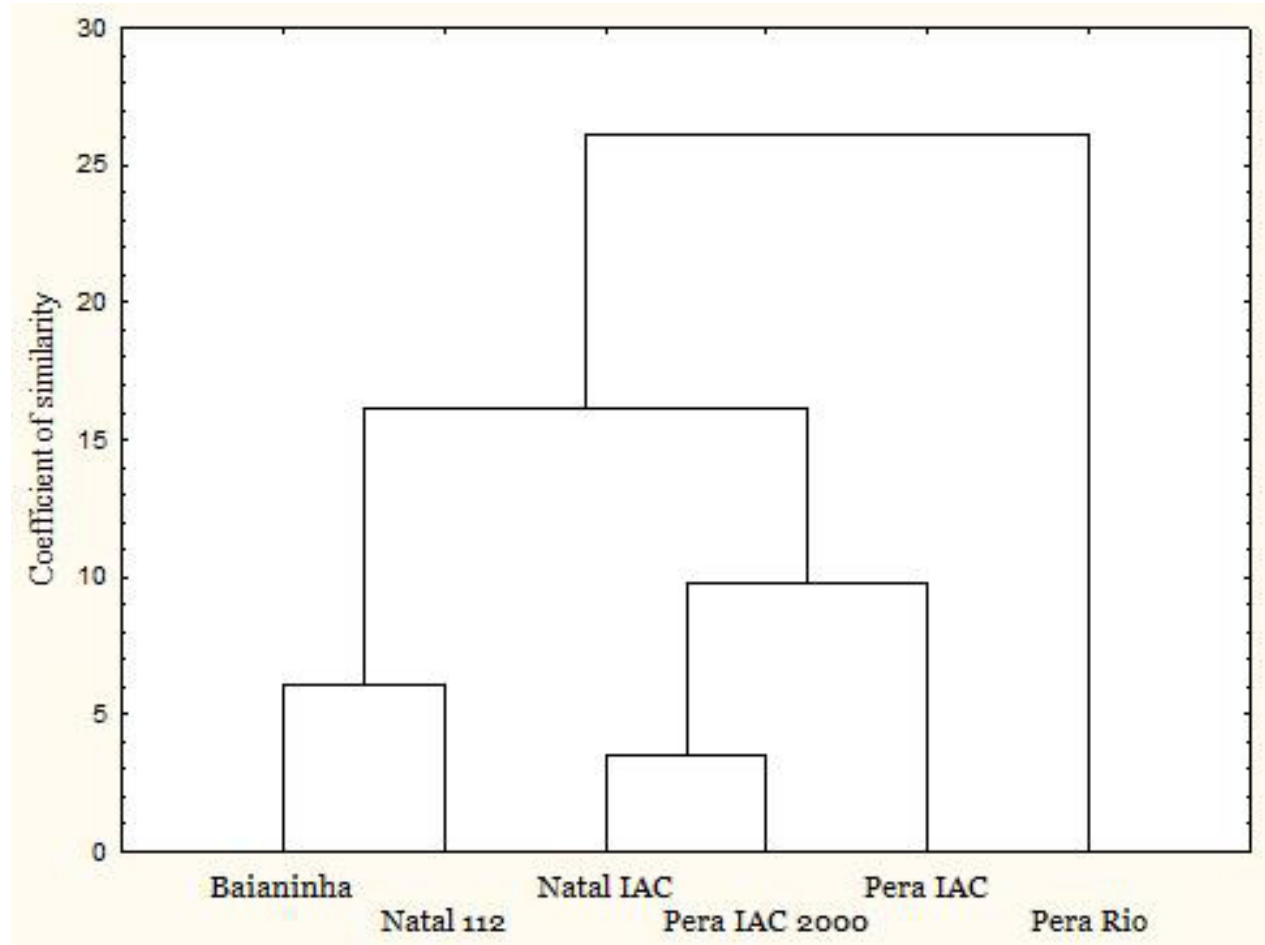

Figure 2. Dendrogram showing the general Euclidean distance among orange cultivars in relation to chemical characteristics and total antioxidant activity, from the experimental orchard of the Agency for Technical Assistance and Agricultural Research of Goiás (EMATER), Anápolis, Goiás, Brazil, 2016.

\section{Conclusions}

Among cultivars, 'Baianinha' and 'Pera IAC' are alternatives for citrus growers, with potential to be well accepted among consumers and processing industries. 'Baianinha' cultivar may be more suitable for processing industries due to the high acidity levels. 'Pera IAC' cultivar can be indicated both for industry and for fresh consumption because it has characteristics similar to 'Pera Rio' cultivar and higher levels of polyphenols and total antioxidant activity.

\section{References}

ARRUDA, M.C. FISCHERI, I.H.; ZANETTE, M. M; SILVA, B.L. Conservação pós-colheita de laranjas Pêra provenientes de cultivos orgânico e convencional. Citrus Research \& Technology, Cordeirópolis, v.32, n.3, p.161165, 2011.

BATISTA, C.L.L.C. Produção e avaliação da estabilidade de corante hidrossolúvel de urucum. Viçosa: Universidade Federal de Viçosa, 1994. 71 p. 
BORGES, A.C.G.; TOLEDO, J.C. O processo para obtenção da qualidade do suco de laranja concentrado congelado brasileiro. Gestão e produção, São Carlos, v.6, n.2, p.97-110, 1999.

BRASIL. Programa Brasileiro para a Melhoria dos Padrões Comerciais e Embalagens de Hortigranjeiros - Normas de Classificação das tangerinas. São Paulo: Centro de Qualidade em Horticultura, 2000.

IBGE - Instituto Brasileira de Geografia e Estatística. Produção agrícola - lavoura permanente - Goiás. Rio de Janeiro, 2016. Disponível em: $<\underline{\text { https://cidades.ibge. }}$ gov.br/brasil/go/pesquisa/15/0> . Acesso em: 09 fev.2016.

CASTRICINI, A.; SANTOS, L.O.; DELIZA, R.; COELHO, E.F.; RODRIGUES, M.G.V.Caracterização pós-colheita e sensorial de genótipos de bananeiras tipo Prata. Revista Brasileira de Fruticultura, Jaboticabal, v.37, n.1, p.27-37, 2015.

CASTRO, M.C.; LOPES, J.D.; TEIXEIRA, S.M. Municípios goianos: competitividade e concentração na fruticultura. Conjuntura Econômica, Goiana, n.29, 2014.

CERQUEIRA, E.C.; CASTRO NETO, M.T.; PEIXOTO, C.P.; SOARES FILHO, W.S.; LEDO, C.A.S.; OLIVEIRA, J.G. Resposta de portas-enxerto de citros ao déficit hídrico. Revista Brasileira de Fruticultura, Jaboticabal, v.26, n.3. p.515-519, 2004.

CEAGESP - Companhia de Entrepostos e Armazéns Gerais de São Paulo. Programa brasileiro para modernização da horticultura. Normas de classificação de citros de mesa. São Paulo: Centro de qualidade em horticultura, 2011. 12p.

COUTO, M.A.L.; CANNIATTI-BRAZACA, S.G. Quantificação de vitamina $C$ e capacidade antioxidante de variedades cítricas. Ciência e Tecnologia de Alimentos, Campinas, v.30, n.1, p.15-19, 2010.

DUARTE, T.F.; BRON, I.U.; RIBEIRO, R.V.; MACHADO, E.C.; MAZZAFERA, P.; SHIMIZU, M.M. Efeito da carga pendente na qualidade de frutos de laranjeira 'Valencia'. Revista Brasileira de Fruticultura, Jaboticabal, v.33, n.3, p.823-829, 2011.

FERREIRA, D.F. Sisvar: a guide for its bootstrap procedures in multiple comparisons. Ciência e Agrotecnologia, Lavras, v.38, n.2, p.109-112, 2014.
HAIR, J.F.; BLACK, W.C.; BABIN, B. J.; ANDERSON, R.E.; TATHAM, R.L. Análise multivariada de dados. Tradução Adonai Schlup Sant'Anna e Anselmo Chaves Neto. 5. ed. Porto Alegre: Bookman, 2005.

HALLIWELL, B. Vitamin C and genomic stability. Mutation research: fundamental and molecular mechanisms of mutagenesis. New York, v.475, n.1-2, p.29-35, 2001.

INSTITUTO ADOLFO LUTZ. Normas analíticas do Instituto Adolfo Lutz. Métodos físico-químicos para análise de alimentos. São Paulo, 2008. 1020p. Disponível em: <https://wp.ufpel.edu.br/nutricaobromatologia/ files/2013/07/NormasADOLFOLUTZ.pdf $>$ (

KÖPPEN, W.; GEIGER, R. Klimate der Erde. Gotha: Verlag Justus Perthes, 1928. (Wall-map)

MACHADO, M.A.; CRISTOFANI-YALI, M.; BASTIANEL, M. Breeding, genetic and genomic of citrus for disease resistance. Revista Brasileira de Fruticultura, Jaboticabal, v.33, n.1, p.158-172, 2011. Volume especial

McGUIRE, R. G. Reporting of objective color measurement. HortScience, Alexandria, v.27, n.12, p.1254-1255, 1992.

MEDINA, C.L.; MACHADO, E.C.; RENA, A.B.; SIQUEIRA, D.L. de. Fisiologia dos citros. In: MATTOS JÚNIOR, D.; NEGRI, J.D.; PIO, R.M.; POMPEU JÚNIOR, J. Citros. Campinas: Instituto Agronômico, 2005. p.149-195.

NEGREIROS, J.R.D.S.; ANDRADE NETO, R.C.; MIQUELONI, D.P.; LESSA, L.S. Estimativa de repetibilidade para caracteres de qualidade de frutos de laranjeira-doce. Pesquisa Agropecuária Brasileira, Brasília, DF, v.49, p.40-48, 2014.

OECD/FAO. OECD/Food and Agriculture Organization of the United Nations. Paris: OECD-FAO Agricultural Outlook, 2015.

OLIVEIRA, R.P.; SCIVITTARO, W.B. Produção de citros sem sementes. Cultivo de citros sem sementes. Pelotas: Embrapa Clima Temperado, 2011. p.23-28.

PACHECO, C.A.; SCHINOR, E.H.; AZEVEDO, F.A.; BASTIANEL, M.; CRISTOFANY-YALI, M. Caracterização de frutos do tangor TMxLP 290 para mercado de fruta fresca. Revista Brasileira de Fruticultura, Jaboticabal, v.36, n.4, p.805-812, 2014. 
PEREIRA, M.E.C.; CANTILLANO, F.F.; GUTIEREZ, A.S.D.; ALMEIDA, G.V.B. Procedimentos pós-colheita na produção integrada de citros. Cruz das Almas: Embrapa Mandioca e Fruticultura Tropical, 2006. (Documentos, 156).

POZZAN, M.; TRIBONI, H.R. Colheita e qualidade do fruto. In: MATTOS JUNIOR, D; DE NEGRI, J.D.; PIO, R.M.; POMPEU JUNIOR, J. (Ed.). Citros. Campinas: IAC, FUNDAG, 2005. cap.26, p.801-822.

REIS, R.C.; VIANA, E.S.; JESUS, J.L.; SANTOS, T.M.S.; OLIVEIRA, N.A. Physicochemical and sensorial quality of banana genotypes. Pesquisa Agropecuária Tropical, Goiânia, v.46, n.1, p.89-95, 2016.

RUFINO, M.S.M. Propriedades funcionais de frutas tropicais brasileiras não tradicionais. 2008. $237 \mathrm{f}$. Tese (Doutorado em Agronomia) - Universidade Federal Rural do Semiárido, Mossoró, 2008.

SALIBE, A. A.; TEÓFILO SOBRINHO, J.; MÜLLER, G. W. Sinopse de conhecimentos e pesquisas sobre a laranja-'Pera'. Laranja, Cordeirópolis, v.23, n.1, p.231$245,2002$.

SANTOS, R.M.; VALADARES, F.V.; PIROVANI, A.A.V.; VENANCIO, D.F.V.; MOULIN, M.M. Caracterização morfoagronômica e físico-química de germoplasma de citrus. Enciclopédia Biosfera, Goiânia, v.13 n.23, p.13981410, 2016.

SCHWARZ, S. F. Melhoramento genético e variedades. In: KOLLER, O.C. (Org.). Citricultura: 1. Laranja: tecnologia de produção, pós-colheita, industrialização e comercialização. 2.ed. Porto Alegre: Cinco Continentes, 2011. p.9-18.

SNART, J. E.; ARPAYA, M. L.; HARRIS, L. J. Oranges: safe methods to store, preserve, and enjoy. California: UCANR Publications, 2007.
SOUZA, M.J.H.; RAMOS, M.M.; SIQUEIRA, D.L.; MANTOVANI, E.C.; COSTA, L.C.; LHAMAS, A.J.M.; CECON, P.R.; SALOMAO, L.C.C. Graus-dia e duração do subperíodo antese-colheita da lima ácida 'Tahiti' em condições de sequeiro e irrigado. Revista Brasileira de Agrometeorologia, Santa Maria, v.13, p.35-43, 2005.

STATSOFT. STATISTICA (data analysis software system). Version 7.0. Cary, 2004.

STROHECKER, R.L.; HENNING, H.M. Analisis de vitaminas: métodos comprobados. Madrid: Paz Montalvo, 1967. 428p.

TAZIMA, Z.H.; NEVES, C.S.V.J.; YADA, I.F.U.; LEITE JUNIOR, R.P.Produção e qualidade dos frutos de clones de laranjeira 'Pera' no norte do Paraná. Revista Brasileira de Fruticultura, Jaboticabal, v.32, n.1, p.189-195, 2010.

TEIXEIRA, L.V. Análise sensorial na indústria de alimentos. Revista do Instituto de Laticínios Cândido Tostes, Juiz de Fora, v.64, n.366, p.12-21, 2009.

TERUEL, M.B.J.; CORTEZ, L.A.B.; LEAL, P.A.; NEVES FILHO, L.C. Caracterização pós-colheita de laranjas 'Baianinha' submetidas ao armazenamento refrigerado e a condições ambientais. Horticultura Brasileira, Brasília, DF, v.18, n.1, 2000.

UNICAMP - Universidade Estadual de Campinas. Tabela brasileira de composição de alimentos: TACO. 4 ed. Campinas, 2011.

YU, L.; HALEY, S.; PERRET, J.; HARRIS, M.; WILSON, J.; QIAN, M. Free radical scavenging properties of wheat extracts. Journal of Agricultural and Food Chemistry, Freising, v.50, n.6, p.1619-1624, 2002. 